\title{
Conversion of Transuranic Waste to Low Level Waste by Decontamination - A Site Specific Update
}
R. P. Allen
R. F. Hazelton

September 1985

Prepared for the U.S. Department of Energy under Contract DE-AC06-76RLO 1830

Pacific Northwest Laboratory Operated for the U.S. Department of Energy by Battelle Memorial Institute 


\section{DISCLAIMER}

This report was prepared as an account of work sponsored by an agency of the United States Government. Neither the United States Government nor any agency thereof, nor any of their employees, makes any warranty, express or implied, or assumes any legal liability or responsibility for the accuracy, completeness, or usefulness of any information, apparatus, product, or process disclosed, or represents that its use would not infringe privately owned rights. Reference herein to any specific commercial product, process, or service by trade name, trademark, manufacturer, or otherwise, does not necessarily constitute or imply its endorsement, recommendation, or favoring by the United States Government or any agency thereof. The views and opinions of authors expressed herein do not necessarily state or reflect those of the United States Government or any agency thereof.

\section{PACIFIC NORTHWEST LABORATORY operated by \\ BATTELLE \\ for the \\ UNITED STATES DEPARTMENT OF ENERGY under Contract DE-AC06-76RLO 1830}

\begin{tabular}{|c|c|}
\hline \multicolumn{2}{|c|}{ Printed in the United States of America } \\
\hline \multicolumn{2}{|c|}{ Available from } \\
\hline \multirow{4}{*}{\multicolumn{2}{|c|}{$\begin{array}{c}\text { National Technical Information Service } \\
\text { United States Department of Commerce } \\
5285 \text { Port Royal Road } \\
\text { Springfield, Virginia } 22161\end{array}$}} \\
\hline & \\
\hline & \\
\hline & \\
\hline \multirow{2}{*}{\multicolumn{2}{|c|}{$\begin{array}{l}\text { NTIS Price Codes } \\
\text { Microfiche A01 }\end{array}$}} \\
\hline & \\
\hline \multicolumn{2}{|c|}{ Printed Copy } \\
\hline & Price \\
\hline Pages & Codes \\
\hline $001-025$ & $\mathrm{~A} 02$ \\
\hline $026-050$ & A03 \\
\hline $051-075$ & A04 \\
\hline $076-100$ & A05 \\
\hline $107-125$ & A06 \\
\hline $126-150$ & A 07 \\
\hline $151-175$ & A08 \\
\hline $176-200$ & A09 \\
\hline $201-225$ & A010 \\
\hline $226-250$ & A011 \\
\hline $251-275$ & A012 \\
\hline $276-300$ & A013 \\
\hline
\end{tabular}


PNL -5570

UC -70

CONVERSION OF TRANSURANIC WASTE TO LOW LEVEL WASTE BY DECONTAMINATION - A

SITE SPECIFIC UPDATE

R. P. Alten

R. F. Hazelton

September 1985

Prepared for the U.S. Department of Energy under Contract DE-AC06-76RLO 1830

Pacific Northwest Laboratory Richland, Washington 99352 


\section{SUMMARY}

As a followup to an FY-1984 cost/benefit study (Allen 1984), a program was conducted in FY-1985 to transfer to the relevant DOE sites the information and technology for the direct conversion of transuranic (TRU) waste to low-level waste (LLW) by decontamination. As part of this work, the economic evaluation of the various TRLW volume reduction and conversion options was updated and expanded to include site-specific factors. The results show, for the assumptions used, that size reduction, size reduction followed by decontamination, or in situ decontamination are cost effective compared with the no-processing option.

The technology transfer activities included site presentations and discussions with operations and waste management personnel to identify application opportunities and site-specific considerations and constraints that could affect the implementation of TRU waste conversion principles. These discussions disclosed definite potential for the beneficial application of these principles at most of the sites, but alsc confirmed the existence of site-specific factors ranging from space 1 imitations to LLW disposal restrictions that could preclude particular applications or diminish expected benefits. 
$\because$

$\checkmark$

. 


\section{ACKNOWLEDGEMENTS}

The helpful suggestions and continuing encouragement of this work by P. G. Hagan of the Joint Integration Office of the U. S. Department of Energy Trasuranic Waste Lead Organization are gratefully acknowledged. Appreciation also is extended to many individuals at the various Department of Energy sites and contractor organizations for their valuable time, helpful suggestions and interest in this work. 


\section{-}




\section{CONTENTS}

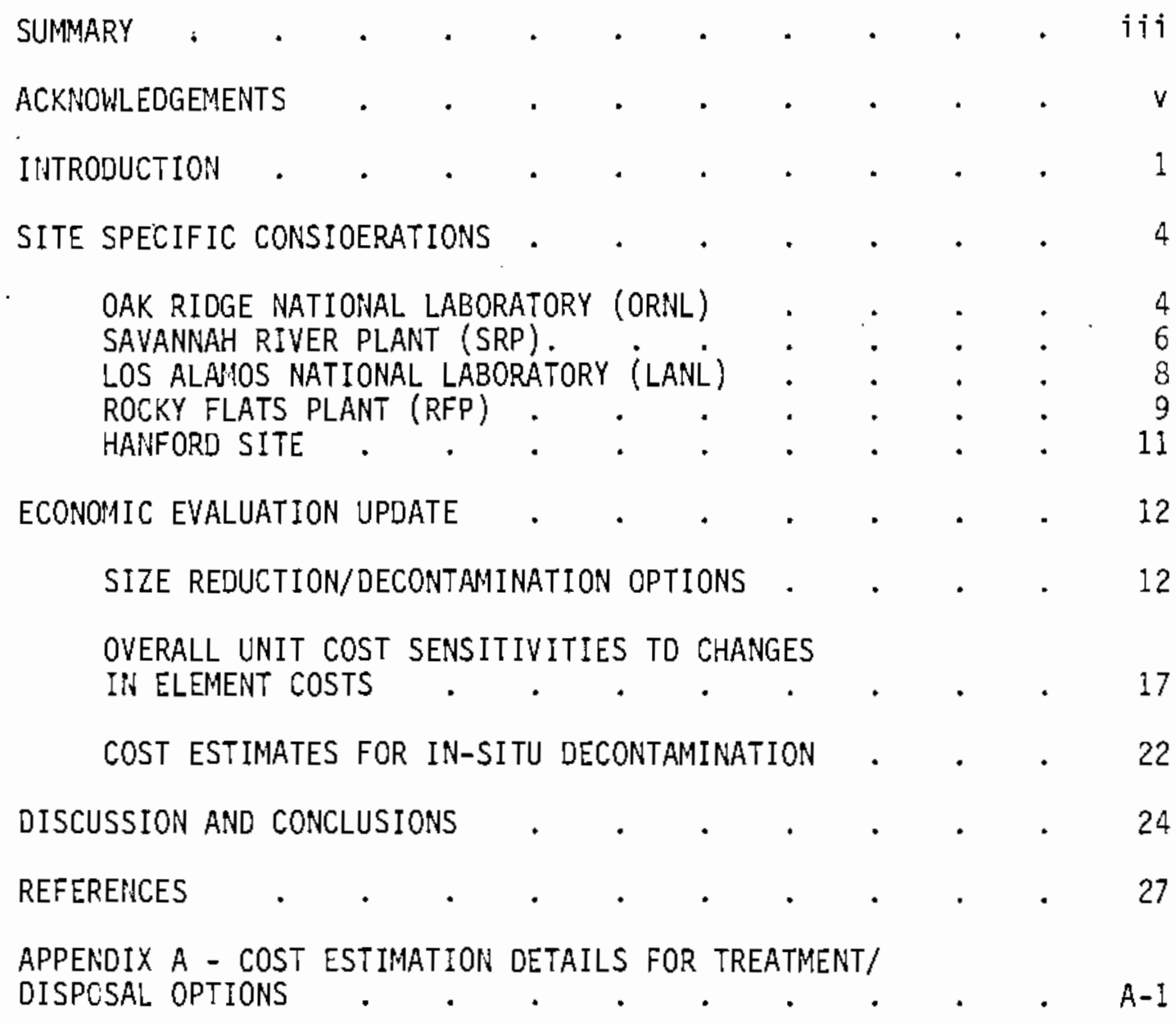




\section{TABLES}

1 Unit costs, $\$ / \mathrm{m}^{3}$ of Original waste Volume, for TRUContaminated Glove Box Waste Shipped to WIPP by Rail . 14

2 Unit Costs, $\$ / \mathrm{m}^{3}$ of Original Waste Volume, for TRU Contaminated. Gove Box Waste Shipped to WIPP by Truck . 18

3 Effects of Change on Overall Costs (Railroad Transportation) . . . . . . . . . 19

4 Effects of Change on Overall Costs (Truck Transportation)

\section{FIGURES}

1 Sensitivity of Overaly Unit Cost to a Change in an Element Unit Cost for Processing TRU-Contaminated Glove Boxes (Truck Transportation). . . . . 25

2 Total Unit Cost for TRUW Handling and Disposal Options, $\$ / \mathrm{m}^{3}$ of Original Glove Box Volume (Truck Transportation) 


\section{CONVERSION OF TRANSURANIC WASTE TO LOW LEVEL WASTE BY DECONTAMINATION - A SITE SPECIFIC UPDATE}

\section{INTROOUCTION}

One direct means of reducing the cost and potential handling and transportation hazards associated with the management and uitimate disposal of transuranic (TRU) waste is to reduce the amount and TRU content of this waste. Substantial work has been conducted to develop and field demonstrate advanced assay instrumentation to facilitate the identification and segregation of low-level waste (LLW). The Joint Integration Office, through its Reduction in Waste Arisings program activities, has identified four other areas that offer significant opportunity for further reduction in the volume and TRU content of defense related TRU waste streams. These are:

- Administrative control - This inciudes control of types and quantities of material introduced into process areas, information exchanges and awareness training programs, and review/preparation of flow sheets for methods to reduce the production of waste materials.

- Materials substitution - This includes the design, treatment or coating of equipment, tools and materials to extend usefulness and life span or to provide longer-lasting or ease-of-decontamination qualities.

- Process development or optimization - This includes the improvement of current processes or the development of replacement processes to effect a reduction in waste for common operations such as materials dissolution, ion exchange, solvent extraction and precipitation.

- New equipment utilization - This includes the use of new equipment, such as bagless posting systems, to effect a reduction in the waste from process or production operations. 
As part of the Administrative Control program activities, an FY-1984 study (Allen 1984) was conducted at Pacific Northwest Laboratory $(P N L)^{(a)}$ to provide analyticai data for ways in which newly generated defense waste can be changed from the TRU waste category into the LLW category by decontamination. This study included a review and update of previous analyses and evaluations of volume reduction and conversion options (Brown 1982; Allen 1982). Major emphasis, however, was on a technical feasibility and cost/benefit evaluation of the use of in situ decontamination techniques to convert glove boxes and other large TRU-contaminated components directly into LLW.

The results of this study indicated that in situ decontamination of these types of components to non-TRU levels is technically feasible. Applicable decontamination techniques include electropolishing, hand scrubbing, chemical washes/sprays, strippable coatings and Freon ${ }^{\circledR}$ spraycleaning. The removal of contamination from crevices and other holdup areas is a probiem, but may be solved through further advances in decontamination technology.

The economic evaluation indicated, for the assumptions used, that there was a definite cost incentive to size reduce large components, and that decontamination of sectioned material had become cost competitive with the size reduction options. In situ decontamination appeared to be the lowest cost option when based on routine-type operations conducted by well-trajned and properly equipped personnel.

Based on these findings, a program was conducted in FY-1985 to transfer to the relevant DOE sites the information and technology for the direct conversion of TRU waste to LLW. This was accomplished primarily through presentations at the sites and at national and internationar workshops. The site presentations were designed to encourage adaptation and utilization of new and improved technologies.

As part of the site presentations, discussions were held with personne] representing both the operations and the waste management

(a) Operated by Battelle Memorial Institute.

- Freon is a registered trade name of E. I. du Pont de Nemours, Nemours Bldg., Wilmington, Delaware. 
functions to identify site-specific cost elements and operational and administrative considerations and constraints that could affect the application of the TRU waste conversion principles. The purpose of the present report is to supplement and update the FY-1984 study (Allen 1984) by 1) discussing site-specific cost factors and other considerations affecting the value and applicability of these TRU waste conversion principles for the various sites; and 2) updating the economic evaluation of TRU waste volume reduction and conversion options and including sensitivity analyses for cost elements with large uncertainties. 


\section{SITE SPECIFIC CONSIDERATIONS}

The results of the economic evaluation update continue to support the cost effectiveness and competitiveness of the size reduction and decontamination TRU waste management options from a generic standpoint. There are, however, a number of site-specific cost elements and operational and administrative considerations and constraints that could alter this conclusion for particular sites and applications.

The following section addresses these site specific considerations starting with a site overview to provide background information on TRU waste characteristics, followed by a discussion of site-related economic factors, and concluding with suggestions for possible implementation of TRU waste conversion principies within the context of the specific site constraints and considerations.

OAK RIDGE NATIONAL LABORATORY (ORNL)

\section{Site Overview}

Personnel from ORNL and other DOE sites and offices conduct a continuing data base program on spent fuel and radioactive waste inventories, projections, and characteristics. DRNL prepares a report annually updating the data (Oak Ridge National Laboratory 1984). The data for 1983 on contact-handled (CH) TRU waste (a) given in this report are presented under the site overview heading for the particular site being discussed.

The estimated inventory of TRU waste in retrievable storage at ORNL as of December 31,1983 , was $450 \mathrm{~m}^{3}$. The projected TRU waste generation is $28 \mathrm{~m}^{3} / \mathrm{yr}, 100 \%$ of which is listed as certifiable. About $16 \mathrm{vo} \%$ of the retrievably stored TRU waste is metal, 56 vol\% combustibles, and 28 vol\% other materials.

(a) TRU waste, as used throughout this report generaliy refers to contact-handled TRU waste. Remote-handled TRU waste is specifically designated as RH-TRU waste. 
Site Economic Factors

Glove boxes are usually handled by the waste generator, owner (b). Attempts are made to decontaminate them to less than TRU waste limits for burial. If less than TRU waste limits are unattainable, the glove boxes are sealed and packaged in Type A DOT containers. The legs of a glove box may be removed, but there is no further dismantling. This pre-storage processing cost is about $\$ 600$. The glove boxes are either left in place or stored at the waste handling facilities.

The one time charge for TRU waste storage is currently about $\$ 710 / \mathrm{m}^{3}$; that for LLW is $\$ 205 / \mathrm{m}^{3}$.

For other types of $\mathrm{CH}-\mathrm{TRU}$ waste, several types of containers may be used. Currently, 304-L stainless steel 55-gal drums are used which cost $\$ 240$ each; this is being changed to 316 stainless steel having better corrosion resistance at a cost of $\$ 268$ per drums. Type A metal boxes of 3.1 to $6.0 \mathrm{~m}^{3}$ capacity are also used at a cost of $\$ 800$ for either size. Another container used for $\mathrm{CH}-T R U$ waste is a $9.9 \mathrm{~m}^{3}$ cement cask, which costs about $\$ 1,200$ each.

TRU waste now in storage is being assayed for nuclides at an estimated cost of $\$ 350 / \mathrm{m}^{3}$. Later, drums of waste will be $x$-rayed at an additional estimated cost of $\$ 350 / \mathrm{m}^{3}$.

Other Site Considerations

The unique aspect of the total ORNL TRU waste is the comparatively Targe proportion of remote-handled RH-TRU waste. About one-half of the total TRU waste in storage and that newly generated is high-exposure RH-TRU waste from hot ceil operations. This waste includes both metallic and non-metallic material, typically in a size range permitting packaging in one gallon buckets. Much of this waste, such as metal, glass, plastics and rubber, would be ideal for remote decontamination to the non-TRU category using vibratory finishing technology. Site personnel feel that a significant cost savings could be effected if the volume of RH-TRU waste currently stored in concrete casks could be

(b) Economic factors for the sites discussed were obtained by telephone from waste management personnel at each site. 
reduced. However, there is no way to handle the casks without a new facility. Currently, there is not sufficient space associated with the hot cell operations even to accommodate a small vibratory finisher for the newly generated RH-TRU waste.

The CH-TRU waste at ORNL is typical glove box waste. Much of this waste also could be converted to LLW by vibratory finishing if space were available for a processing system. However, preliminary assay results indicate that a large fraction of the CH-TRU waste actually is non-TRU.

Some glove boxes have been removed from service and placed in WIPPacceptable containers without size reduction. In general, there does not appear to be an opportunity for significant application of in situ decontamination methods. One problem associated with the conversion of TRU waste to LLW is a potential shortage of LLW burial ground. The site is planning to use compaction of LLW to extend the life of the existing disposal facilities.

SAVANNAH RIVER PLANT (SRP)

Site Overview

The estimated inventory (ORNL 1984) of TRU waste in retrievabie storage at SRP as of Oecember 31,1985 , was $3,399 \mathrm{~m}^{3}$. The projected TRU waste generation is $425 \mathrm{~m}^{3} / \mathrm{yr}$ with 30 vol\% estimated as being certifiable. SRP records indicate only whether the waste is a combustible or noncombustible classification, with the waste breakdown being 70 vol\% combustible, 30 vol\% noncombustible.

\section{Site Economic Factors}

Idled glove boxes at SRP, as described by SRP waste management, are now boxed up in plywood crates, which in turn go into custom-made stee? boxes. These boxes are then placed on interim-storage TRU waste pads. The annual volume of glove box disposal is small. 
Most of the TRU waste being generated is job control waste cloths, clothing, tools. Noncombustibles are mostly tools. The waste is put into 55-gal drums which are placed on an interim-storage TRU waste pad at an estimated cost of $\$ 90$ per drum (equivalent to $\$ 430 / \mathrm{m}^{3}$ ). If there is greater than $0.5 \mathrm{Ci} /$ drum, the drum is placed into a concrete culvert, which can hold fourteen drums at a cost of $\$ 325$ per drum $\left(\$ 1,150 / \mathrm{m}^{3}\right)$. Culverts are placed side by side on a concrete pad.

Costs for retrieval and certification of TRU waste are currently uncertain. The cost for shallow land, trench burial of solid LLW is about $\$ 140 / \mathrm{m}^{3}$.

Other Site Considerations

The unique aspect of TRU waste at SRP is the presence of significant amounts of plutonium-238 and other less-common TRU isotopes. This results in an exposure problem that precludes the extensive type of in situ decontamination operation treated in the FY-1984 study (Allen 1984). Strippable coatings are used to remove gross contamination, but the high specific activity of the plutonium-238 can result in self-heating problems as well as excessive hydrogen generation concerns. Previous studies conducted both at SRP and at Hanford also suggest that this isotope is more difficult to remove even using advanced decontamination techniques such as electropolishing.

Although these considerations suggest that direct in situ decontamination of glove boxes and other TRU-contaminated components to non-TRU waste levels may not be advisable or technically feasible, the SRP plans for TRU waste management already include extensive remote component decontamination operations as part of the Disassembly and Decontamination Facility operations (Cadieux et al. 1982). The intention is to remove more than $99 \%$ of the surface activity from the component, with minimai disassembly, using chemical decontamination sprays. The waste subsequently will be remotely disassembled and sectioned for volume reduction. Additional decontamination operations may be conducted using electropolishing, vibratory finishing or chemical etching to convert the TRU waste to LLW for disposal in the SRP burial ground. 
LOS ALAMOS NATIONAL LABORATORY (LANL)

Site Overview

LANL had $6,295 \mathrm{~m}^{3}$ of retrievably stored TRU waste as of December $31,1983,\left(0 R N L\right.$ 1984). The projected TRU waste for 1984 was $454 \mathrm{~m}^{3}$, and for $1985-1993,338 \mathrm{~m}^{3} / \mathrm{yr}$ with $100 \%$ being certifiable after 1985 . The physical composition estimated for retrievably stored waste was 39.3 vol\% metal, 8.9 vol\% glass, 18.1 vol\% liquids or sludges, 16.6 vol\% combustibles, 11.9 vol\% concreted or cemented sludges, and the remainder being miscellaneous materials.

Site Economic Factors

A need for room area is the driving force for removal of an idled glove box from its former use position. Until recently, a glove box being removed would be wiped down, disconnected, and placed into a fiber glass-coated box built to size for the glove box. The containers were generally too large to be sent to WIPP.

LANL is now developing a size reduction capability so that glove boxes can be size reduced. Rough cost estimates indicate that the processing cost will be around $\$ 1,200 / \mathrm{m}^{3}$. This cost will cover receipt of a glove box at the facility, cutting, bagging out cut pieces, placing material into a WIPP approved container, and certification. The waste will be sent to WIPP. Subsequent storage costs and retrieval costs for the certified waste are uncertain. The above cost also does not cover on-site storage and retrieval before size reduction. Predicting an allinclusive cost is extremely complex because LANL has a variety of unique processes and facilities to do the many different operations that may be required.

The cost of LLW burial by LANL is about $\$ 110$ to $\$ 140 / \mathrm{m}^{3}$. This excludes costs before receipt of the waste at the disposal site. 0ther Site Considerations

LANL has potential for significant beneficial application of TRU waste conversion principles inciuding direct in situ decontamination processes. Almost $50 \%$ of the TRU waste generated and stored at LANL 
consists of glove boxes and other large metallic components contaminated primarily with plutonium-239. More than 200 glove boxes currently are in storage and future activities could produce a similar quantity for processing and disposal.

The general approach for large TRU contaminated components at LANL. is to decontaminate in place to the extent possible and then as discussed earlier, size reduce using the recently constructed Size Reduction Facility (SRF). Site personne? have expressed an interest in additional information and application results for direct in situ glove box decontamination technology and also for facility related applications.

ROCKY FLATS PLANT (RFP)

Site Overview

ORNL (1984) lists no stored TRU waste at RFP. The RFP TRU waste is sent to INEL; LLW, to the Nevada. Test Site at present. The projected annual TRU waste generation ranges from $3000 \mathrm{~m}^{3}$ for 1984 (2 vol\% being certifiable) to $4000 \mathrm{~m}^{3}$ by 1988 , with 100 vol\% being certifiable. No composition breakdown is given by ORNL (1984).

Site Economic Factors

Construction of the Advanced Size Reduction Facility (ASRF) will be completed in the Fall of 1985. This facility, described by Mitchell, Aguilar, and Williams (1984), will be used to section $1.8 \times 2.4 \times 3.0 \mathrm{~m}$ glove boxes and miscellaneous equipment to a size for placement into a $2.4 \mathrm{~m}^{3}$ WIPP-approved waste container. The volume reduction target is two to one. The capital cost of ASRF is $\$ 9.6 \mathrm{million}$; the operating cost is estimated to be $\$ 330 / \mathrm{m}^{3}$ of original glove box volume. This latter cost includes placing the size-reduced material into the container, but excludes container preparation and shipping. The base cost for the older RFP facility was about $\$ 640 / \mathrm{m}^{3}$ just to have personnel in the size reduction cell.

Certification costs for WIPP disposal are unavailable; these are not separated from an operations effort. 
LLW waste has been packaged in several type containers. Before 1984 , a $1.2 \times 1.2 \times 2.1 \mathrm{~m}$ plywood box was used at a cost of $\$ 82 / \mathrm{m}^{3}$. A metal box is now used at a cost of $\$ 190 / \mathrm{m}^{3}$. The cost of LLW 55-gal drums is $\$ 28.34$ each; a 1984 cost for TRU drums was $\$ 58.50$. LLW is shipped to the Nevada Test Site at a cost of $\$ 4.33$ per hundred weight; TRU waste to INEL at a cost of $\$ 5.46$ per hundred-weight. The disposal cost for LLW at the Nevada site is about $\$ 200 / \mathrm{m}^{3}$. other Site Considerations

RFP also has significant potential for cost effective application of TRUW conversion principles, but implementation appears limited by operational and LLW handling constraints. Glove boxes and other large metailic components currently are size reduced in an existing manually operated facility. This will shortly be replaced by the new Advanced Size Reduction Facility (ASRF) that will permit disassembly, sectioning, steam cleaning and packaging of TRU-contaminated components using remote handling and processing techniques.

Glove boxes currently are cleaned in place by operational groups before removal, but only to satisfy materials accountability requirements. Decontamination probably would become a waste management responsibility for a major stripout operation, but time constraints would not permit extensive in situ decontamination for TRU waste conversion purposes. Space restrictions similarly would limit post-disconnection decontamination efforts.

TRU waste conversion decontamination applications also are Timited by the lack of a size reduction facility for LLW. Currently, some LLW must be processed as TRU waste because of this restriction. From this standpoint, the decontamination of sectioned waste to non-TRU levels would be more cost effective than direct conversion using in situ technology. Once the ASRP is operation, however, the manual size reduction facility will be used to section LLW.

Advanced decontamination technology also could be used for Pu recovery if criticality safety concerns could be adequately addressed. Another potential RFP decontamination application is the reclamation and recycle of tools and materials. 
HANFORD SITE

Site Overview and Economic Factors

The volume of TRU waste in storage (ORNL 1984) at Hanford as of December 31,1983 , was estimated to be $12,808 \mathrm{~m}^{3}$. The projected rate of TRU waste generation varies from $813 \mathrm{~m}^{3}$ (50 vol\% certifiable) for 1984 to $175 \mathrm{~m}^{3} /$ per $\mathrm{yr}$ between 1986 and 1990 (50-75 vol\% certifiable) to 210 $\mathrm{m}^{3}$ /per yr from 1990-1994 (75-100 vol\% certifiable). The Hanford retrievably stored waste composition was reported as 48.7 vol\% metals, 23.3 vol\% combustibles, and the remainder as miscellaneous materials.

Other Site Considerations

Stored TRU waste from the Hanford site and offsite generators ultimately will be processed as required for WIPP-Waste Acceptance Criteria compliance using the planned Waste Receiving and Processing (WRAP) Facility. This will include sectioning of oversize components, but no decontamination of sectioned material for TRU waste conversion. In situ decontamination operations have been conducted for glove boxes to reduce gross contamination levels in preparation for transport and size reduction. There appear to be many site opportunities for direct conversion of glove boxes, tanks and other components to the LLW category. However, as noted previously (Allen 1984), realization of the benefits of this approach require well-trained, experienced personnel, and an operational environment that permits minimization of time, exposure, and secondary waste. 


\section{ECONOMIC EVALUATION UPDATE}

An objective of this study was to update the economic data given previously (Allen 1984) to permit a current cost/benefit comparison of the in situ TRU waste conversion approach with other handling, processing and disposal options ranging from direct packaging of a glove box through size reduction, decontamination of sectioned material and/or treatment using major-site waste processing facilities. The following sections address the estimated costs for these various options.

\section{SIZE REDUCTION/DECONTAMINATION OPTIONS}

TRU-contaminated glove boxes must be disposed of as TRU waste or be decontaminated to LLW when their service is no longer required. The objective of this portion of the study was to evaluate the economics of a few alternative handling and disposal methods involving size reduction and decontamination for representative, inactive Hanford site glove boxes.

The TRU-contaminated components used as a basis in this study are two typical $1.2 \times 1.2 \times 2.4 \mathrm{~m}$ glove boxes and three conveyor sections having a total original waste volume of $8.92 \mathrm{~m}^{3}$ and a total weight of $1510 \mathrm{~kg}$. The original density of this waste is thus $170 \mathrm{~kg} / \mathrm{m}^{3}$. This is the same basis as used previously by Allen (1982). The disposal methods are compared by relative unit costs, i.e., $\$ / m^{3}$ of original waste volume. For purposes of deriving relative costs a fixed original volume of $180 \mathrm{~m}^{3}$ was assumed; this is the estimated amount of contact-handled, new, metal waste generated at the Hanford site as used by 8rown (1982, p. 3-2).

Principal factors affecting handling and disposal costs are the extent of size reduction of the glove boxes, the approved, high integrity disposal container in which glove box parts would be placed, whether glove box parts would be decontaminated, and transportation.

It was assumed that the TRU waste containers would be shipped to the WIPP facility for disposal; LLW produced by decontamination would be disposed of at the Hanford site. 
The elements examined for comparison of costs are:

- containers

- certification

- interim storage

- retrieval

- railroad or truck transportation to WIPP
- emplacement at WIPP

- size reduction

- decontamination

- LLW disposar

Aiternative Methods for Glove Boxes

Four alternative methods other than in situ decontamination for handling and processing glove boxes were evaluated and their unit costs are shown in Table 1. These are discussed below. Cost details are given in the Appendix.

Case 1.

A single, high integrity disposal container having external dimensions of $2.8 \mathrm{~m}(\mathrm{~L}) \times 1.7 \mathrm{~m}(\mathrm{~W}) \times 1.8 \mathrm{~m}(\mathrm{H})$ is used for each intact glove box. The container cost is estimated to be $\$ 3,300$. No size reduction is performed in this case, but some miscellaneous handling costs are incurred. The lack of size reduction results in a waste packing density of about $100 \mathrm{~kg} / \mathrm{m}^{3}$ as opposed to the original of $170 \mathrm{~kg} / \mathrm{m}^{3}$. This results in a substantially higher total unit cost (see Table l) as compared with the total cost of the other alternatives in which the packing density is increased.

After packaging of the TRU waste, the containers are determined to be certifiable, and placed into interim storage. Later they are retrieved, overpacked as necessary, shipped to WIPP by railroad, and emplaced. Certification costs were derived from estimates of labor required to review glove box histories and prepare certification checksheets for each container of TRU waste to assure that it is certifiable. Storage and retrieval unit costs are those currently estimated for Hanford for certifiable TRU waste; the costs are, respectively, $\$ 1,216$ and $\$ 1,770$ per $m^{3}$. The volume basis used by a long-established Hanford convention is the internal voiume for drums $\left(0.21 \mathrm{~m}^{3} / 55-\mathrm{ga}\right.$ ) drum) and the external volume of other type containers. Railroad transportation 
TABLE 1. Unit Costs, $\$ / \mathrm{m}^{3}$ of Original Waste Volume for TRU-Contaminated Glove Box Waste Shipped to WIPP by Rail

(1985 Dollars)

\begin{tabular}{|c|c|c|c|c|}
\hline & Case 1 & Case 2 & Case 3 & Case 4 \\
\hline Containers & 739 & 170 & 97 & 40 \\
\hline Certification & 56 & 53 & 209 & 30 \\
\hline Storage & 2,440 & 615 & 316 & 13 \\
\hline Retrieval & 3,540 & 894 & 459 & 18 \\
\hline Railroad Transportation & 1,870 & 531 & 469 & 19 \\
\hline TRUW Disposal (WIPP) & 1,550 & 390 & 244 & 10 \\
\hline Size Reduction & 47 & 407 & 2,220 & - \\
\hline Decontamination & -- & -- & -- & 2600 \\
\hline LLW Disposal & - & - & $=$ & 34 \\
\hline TOTAL, Rounded & 10,200 & 3,100 & 4,000 & 2800 \\
\hline
\end{tabular}

\section{Case Description}

Case 1. Little size reduction is used. Glove boxes are placed inside $2.8 \mathrm{~m}(\mathrm{~L}) \times 1.7 \mathrm{~m}(\mathrm{~W}) \times 1.8 \mathrm{~m}(\mathrm{H})$ containers which, in turn, are placed into TRUPACT bimodal shipping containers and transported by rail to WIPP for disposal.

Case 2. Glove boxes are size reduced so that the waste can be placed into $1.7 \mathrm{~m}(\mathrm{~L}) \times 1.4 \mathrm{~m}(\mathrm{~W}) \times 0.97 \mathrm{~m}(\mathrm{H})$ containers.

Case 3. Glove boxes are size reduced so that the waste can be placed into 55-gallon drums for individual handling and shipment; the drums are handled as a six-pack.

Case 4. The waste from Case 3 is slightly size reduced beyond that of Case 3 and decontaminated by vibratory finishing. More than $96 \%$ of the original waste volume is disposed of as LLW. The small amount of secondary TRU waste is solidified and packaged in drums for handling and disposal as in Case 3. 
cost estimates were derived from rail charge formulas (McNair, et al. 1985) and calculated shipment weights and distances (one way - 1986 miles). Included in the transportation cost are the costs for leasing Transuranic Package Transporter (TRUPACT) systems, estimated to be $\$ 270 /$ day for each TRUPACT-I bimodal shipping container (the first package version) for 26 days each round trip. This daily lease cost rate is based on government ownership of the TRUPACT system including two TRUPACT-I shipping containers and a railcar, a total cost of $\$ 1.6$ million, an annual capital recovery rate of $10 \%$, and 300 days $/ y r$ use for the system. Approximate round trip times given by McNair, et. al (1985) were used. An estimated unit cost of $\$ 773 / \mathrm{m}^{3}$ was used as a base cost for WIPP operations. External volumes of the containers were used to derive estimates for total WIPP disposal costs. Size reduction operation costs are further updates based on labor wage indices of those developed by Alien (1982); the size reduction costs used in all the cases evaluated exclude costs required for amortization (or capital recovery) and maintenance of facilities. These bases were also applied in each of the following cases.

Case 2.

The glove boxes are reduced in size so that the parts could be placed into $1.7 \mathrm{~m}(\mathrm{~L}) \times 1.4 \mathrm{~m}(\mathrm{~W}) \times 0.97 \mathrm{~m}(\mathrm{H})$ containers. The waste packing density for this case was estimated to be $350 \mathrm{~kg} / \mathrm{m}^{3}$. A container cost of $\$ 820$ each was used. This is based on data given by a manufacturer of DOE-approved waste disposal containers.

Case 3.

Glove boxes are size reduced by disassembly and sectioning (such as plasma arc cutting) to allow placement of the sectioned parts into 55-gal drums. The density of the waste is increased by sectioning to $660 \mathrm{~kg} / \mathrm{m}^{3}$. The cost of each TRU waste drum is $\$ 70$.

The 55-gal drums are placed into six-packs before being shipped. The cost for bracing was estimated to be currentiy $\$ 50$ per 6 -pack (based on costs given by Brown 1982). Depending on design specifications, bracing costs could be considerably larger. 
Case 4.

Size reduction is used more extensively in this alternative than in Cases 1 and 2 but not much more than that of Case 3 to prepare glove box parts for decontamination. Following size reduction, glove box parts are decontaminated using vibratory finishing (McCoy, Arrowsmith and Alien 1980). The decontaminated materials are placed into 55-gal drums and disposed as LLW at current (FY 1985) Hanford costs of $\$ 137 / \mathrm{m}^{3}$. Secondary wastes are also disposed of in 55-gal drums as TRU waste. The density of the material disposed of as $L L W$ was assumed to be $660 \mathrm{~kg} / \mathrm{m}^{3}$. The size reduction and decontamination unit cost was updated from that used by Allen (1982). This operating cost is based on experience gained using the PNL size reduction facility. Excluded from this cost, as they were in the other cases, are the capital amortization and maintenance costs for size reduction and decontamination facilities.

Comparison of Unit Cost Data - Railroad Transportation

The unit costs for each alternative are compared in Table 1 . With exclusion of capital-related costs, the most cost effective alternative is Case 4 in which glove boxes are extensively size reduced and the parts decontaminated for LLW disposal. The total unit cost for case 4 is $\$ 2800 / \mathrm{m}^{3}$ of original glove box volume.

Size reduction to some extent is required for each aiternative except Case 1. (Some handling costs are included in this category for Case 1.) In this evaluation, Case 1 is the least cost effective $\left(\$ 10,200 / \mathrm{m}^{3}\right.$ of original glove box volume), primarily due to the low packing density. If glove boxes larger than the reference glove box were to be disposed of, some size reduction would be needed to allow placement of the waste into an approved, high integrity overpack container for TRU waste disposal. The unit costs of Cases 2 and 3 , respectively $\$ 3,100$ and $4,000 / \mathrm{m}^{3}$, show the combined effects of size reduction and containerization methods. 
Comparison of Unit Cost Data - Truck Transportation

A major cost shown in Table 1 is for TRUPACT container transportation by railroad. Transportation costs could be reduced significantly if the waste were shipped by truck rather than by railroad car. Although only one TRUPACT container would be used for a truck shipment rather than two as by railroad, time for a round trip would be considerably reduced thus decreasing TRUPACT container lease costs. The daily lease cost for a truck TRUPACT system, consisting of the tractor and trailer and a single TRUPACT container, is estimated to be $\$ 270 /$ day, assuming government ownership, a capital cost of $\$ 800,000$, an annual capital recovery factor of $10 \%$, and a use rate of 300 days/yr. Costs per unit for weight are also less for truck shipments. An example of the effect of using truck transportation is that of Case 3 for which the transportation cost would be reduced from $\$ 469 / \mathrm{m}^{3}$ to $\$ 290 / \mathrm{m}^{3}$ of original waste volume. Similar unit cost reductions would occur for the other cases involving extensive transportation.

The effect of shipping TRU waste by truck for each case is shown in Table 2. Although there is no re-ordering of the cases from highest to lowest unit cost, the difference between Cases 2 and 4 essentially disappears.

OVERALL UNIT COST SENSITIVITIES TO CHANGES IN ELEMENT COSTS

The lower costs of transporting TRU waste by truck rather than by railroad demonstrate that a change in an element unit cost can affect the total or overal1 unit cost $\left(\$ / \mathrm{m}^{3}\right.$ of original waste volume) for a case. An element unit cost change may also affect the cost ranking of the cases. The costs for some elements have large uncertainties; for instance, the unit costs of certification and WIPP disposal may turn out to be significantly larger than the costs as sumed. Consequentiy, the effects of changing these element unit costs were evaluated. In the future, it is possible that interim storage and retrieval costs may be avoided if newly generated TRU waste were sent directly to WIPP. This effect also was evaluated. 
TABLE 2. Unit Costs, $\$ / \mathrm{m}^{3}$ of Original waste Volume, for TRU Contaminated Glove Box Waste Shipped to WIPP by Truck (1985 Dollars)

\begin{tabular}{|c|c|c|c|}
\hline Case $1^{(a)}$ & Case 2 & Case 3 & Case 4 \\
\hline 739 & 170 & 97 & 40 \\
\hline 56 & 53 & 209 & 30 \\
\hline 2440 & 615 & 316 & 13 \\
\hline 3540 & 894 & 459 & 18 \\
\hline 870 & 252 & 290 & 12 \\
\hline 1550 & 390 & 244 & 10 \\
\hline 47 & 407 & 2200 & -- \\
\hline-- & -- & -- & 2600 \\
\hline - & $=$ & -- & 34 \\
\hline 9200 & 2800 & 3800 & 2800 \\
\hline
\end{tabular}

(a) Cases described in Table 1 footnotes: 
TABLE 3. Effects of Change on Overall Costs

(Railroad Transportation)

(1985 Dollars) Cost Element
Changed

Certification

Storage and Retrieval

WIPP Disposal
Degree of Change

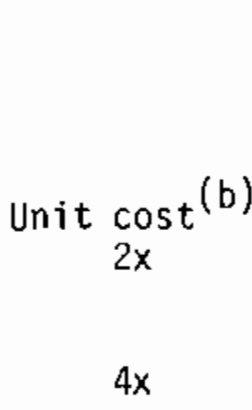

Deleted; waste sent directly to WIPP

Unit cost

$2 x$

$4 x$

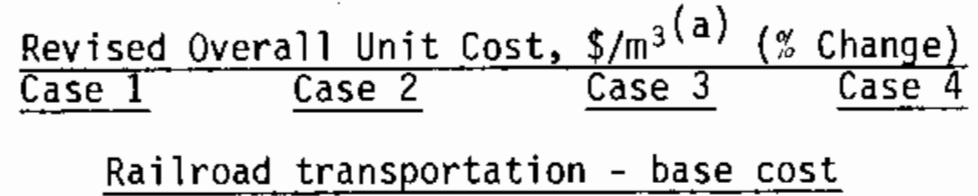

$\begin{array}{llll}10,200 & 3,100 & 4,000 & 2,800\end{array}$

$\begin{array}{rccc}10,300 & 3,100^{(c)} & 4,200 & 2,800 \\ (0.5) & (2) & (5) & (1)\end{array}$

$\begin{array}{cccc}10,400 & 3,200 & 4,600 & 2,900 \\ (2) & (5) & (16) & (3)\end{array}$

$\begin{array}{rrrr}4,300 & 1,600 & 3,200 & 2,700 \\ (-58) & (-49) & (-19) & (-1)\end{array}$

$\begin{array}{rrrr}11,800 & 3,400 & 4,200 & 2,800 \\ (15) & (13) & (6) & (0.4)\end{array}$

$\begin{array}{cccc}14,900 & 4,200 & 4,300 & 2,800\end{array}$

(a) Unit cost, $\$ / \mathrm{m}^{3}$ of original glove box volume.

(b) Revised unit costs and base costs rounded.

c) change based on unrounded costs; effect of change in some instances disappears with rounding of overal1 unit cost. 
TABLE 4. Effects of Change on Overall costs

(Truck Transportation)

(1985 Dollars)

Cost Element Changed

$\tilde{\sigma}$
Degree of

Change

Certification

(1)

Storage and Retrieval

IPP Disposal

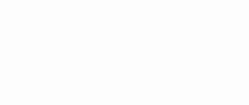

Unit cost ${ }^{(b)}$

$2 x$

$4 x$

Deleted; waste sent directly to WIPP

Unit $\cos t$
$2 x$

$4 x$

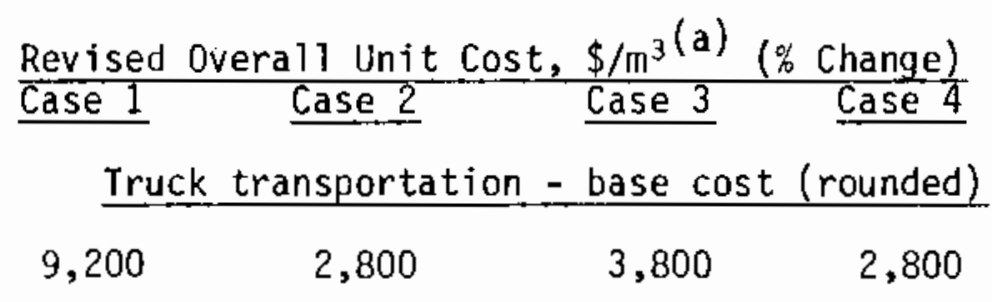

$$
9,300
$$

$$
2,800^{(c)}
$$

4,000

(5)

2,800

9,400

(2)
2,900
(6)

4,440
$(16)$

2,800

$\begin{array}{cccr}3,300 & 1,300 & 3,000 & 2,700 \\ (-65) & (-54) & (-20) & (-1)\end{array}$
10,800
(17)

3,200

(14)
$4,100 \quad 2,800$
$\begin{array}{ll}(6) & (0.4)\end{array}$

13,900

(50)

4,000

(42)

4,500

2,800

(19)

(1)

(a) Unit cost, $\$ / \mathrm{m}^{3}$ of original glove box volume.

(b) Revised unit costs and base costs rounded.

c) change based on unrounded costs; effect of change in some instances disappears with rounding of overall unit cost. 
Tables 3 and 4 show the effects of doubling and quadrupling the unit costs for certification and WIPP disposal, and for avoiding interim storage and retrieval. The tables are for railroad and truck transportation modes, respectively. Figure 1 compares the changes in the overall unit costs for the truck transportation mode.

A change to the certification cost has only a minor impact on overall unit cost, except for case 3 when the certification cost is quadrupled. The overall cost for this case increased about $16 \%$ for both transportation modes. However, the overall cost ranking of the cases was unchanged.

Sending newly generated TRU waste directly to WIPP by railroad, thus avoiding interim storage and retrieval, decreased the overall unit cost of Case 1 for this transportation mode by $58 \%$, Case 2 by $49 \%$, and Case 3 by $19 \%$. This cost avoidance changed the ranking of Case 2 so that it had the least overall unit cost rather than Case 4 . The unit cost for Case 2 decreased from $\$ 3,100$ to $\$ 1,600 / \mathrm{m}^{3}$ of original glove box volume, whereas that for Case 4 decreased by $1 \%$ to $\$ 2,700 / \mathrm{m}^{3}$, or virtually no change. Case 2 also became the most cost effective in the truck transportation mode by this change. The overall unit cost for Case 2 decreased to $\$ 1,300 / \mathrm{m}^{3}$ (a $54 \%$ decrease) from the base of $\$ 2,800 / \mathrm{m}^{3}$; the decrease for Case 4 was again minimal with a change from $\$ 2,800$ to $\$ 2,700 / \mathrm{m}^{3}$ (a $1 \%$ decrease) of original glove box volume.

Doubling and especially quadrupling WIPP disposal costs substantially increased the estimated overall unit costs of Cases 1,2 , and 3 , for either transportation mode, but had little effect on the overall unit cost of Case 4. Little TRU waste is disposed of at WIPP in this latter case. The overall unit cost of Case 1 was increased 45 to $50 \%$ (respectively, railroad and truck transportation) by quadruping the WIPP disposal cost from $\$ 773$ to about $\$ 3100 / \mathrm{m}^{3}$ of original glove box volume. A similar effect, but not to the same degree, was acquired by doubling the WIPP disposal cost. Due to less volume of TRU waste disposed at WIPP, the overall unit cost of Case 3 was not as markedly impacted. The case ranking remained the same as that of the base with 
Case 4 , that involving size reduction and decontamination, being the most cost effective.

\section{COST ESTIMATES FOR IN-SITU DECONTAMINATION}

The cost data and estimates given by Allen (1984) for the in situ decontamination of glove boxes and other representative components to non-TRU levels are based on three sources of information: actual time/cost data from the preparation and manual decontamination of three large glove boxes; a review of previous in situ decontamination operations using other techniques; and discussions with other site and contractor personnel conducting in situ decontamination operations.

The glove box decontamination operations were conducted on three Hanford Site glove boxes contaminated with $\mathrm{Cm}$, Am, Np, Eu, Cs, Sb, Co and $\mathrm{Mn}$. The dimensions of the boxes were:

- $1.2 \times 2.1 \times 3.0 \mathrm{~m}\left(7.9 \mathrm{~m}^{3}\right)$

- $1.2 \times 2.1 \times 4.9 \mathrm{~m}\left(12.7 \mathrm{~m}^{3}\right)$

- $1.2 \times 2.1 \times 4.9 \mathrm{~m}\left(12.7 \mathrm{~m}^{3}\right)$

These glove boxes had been out of service for some time. The exterior surfaces were covered with dirt and debris and the inside contained an inventory of contaminated water in large tanks in addition to other equipment and miscellaneous trash. All of the glove and bag ports were sealed and the exhaust filters had been removed. It was necessary to return the glove boxes to temporary service, perform the decontamination, and then reseal and dispose of the boxes as LLW.

The sequence of operations and labor required for each step are given by Allen (1984). The total labor requirement for the operation, which took five weeks, was 67 man-days. The labor cost at $\$ 50 /$ man-hr was $\$ 46,000$. This included planning, supervision and 5 man-weeks of monitoring coverage. Additional costs were $\$ 5000$ for protective clothing and supplies, and $\$ 14,000$ for disposal of the resulting LLW and secondary TRU waste. The cost of packaging and transporting the decontaminated boxes as LLW was not included as similar charges would be incurred in operations involving handling components for storage or 
processing under the other treatment options. The total cost (1984) for the in situ operations on the $33 \mathrm{~m}^{3}$ of glove box volume was $\$ 65,000$, or about $\$ 1,900 / \mathrm{m}^{3}$ of original volume. A 1985 cost is projected to be $\$ 2,000 / \mathrm{m}^{3}$ by using a one-year escalation factor of $1.05^{(a)}$. It shouid be noted however, that some of the operations, such as water removal, were unique to these particular glove boxes. Wide variations in cost would be expected depending on the size and configuration of the glove boxes, the amount and type of contained equipment, the nature of the surfaces and holdup areas, the extent and type of decontamination employed, and other factors.

(a) The escalation factor was estimated from hourly earnings indices published regularly in the report "Economic Indicators", Chemical Engineering magazine, a McGraw-Hill publication. 


\section{DISCUSSION AND CONCLUSIONS}

The technical evaluation given by Allen (1984) suggests that in situ decontamination of glove boxes and other components to non-TRU levels, particularly under the revised definition of TRU waste, is technically feasible. Electropolishing techniques have the demonstrated capability to reduce contamination levels on even corroded metallic surfaces to non-detectable leveis. Hand scrubbing, chemical washes/ sprays and strippable coatings potentially can ciean accessible surfaces to the required levels, although multiple applications of a single technique or sequential applications of two or more of the techniques may be required.

The results of the updated economic evaluation as sunmarized in Figure 2 show that there continues to be a definite cost incentive to size reduce large components, and that the decontamination of sectioned material has become more cost competitive with the size reduction option. However, as illustrated by the sensitivity evaluation comparisons of Figure 1, any cost advantage of decontamination would be reduced if newly generated TRU waste were sent directly to WIPP and interim storage and retrieval were eliminated. Conversely, if the WIPP disposal cost were to rise markedly, the size reduction-decontamination option would become much more cost effective.

In situ decontamination still appears to be the lowest cost option based on routine-type operations conducted with well trained and properiy equipped personnel. However, as noted in the site-specific discussions, a number of factors relating both to the unique nature of each decontamination project and externaliy-imposed constraints and requirements could alter this conclusion for particular sites and applications. 


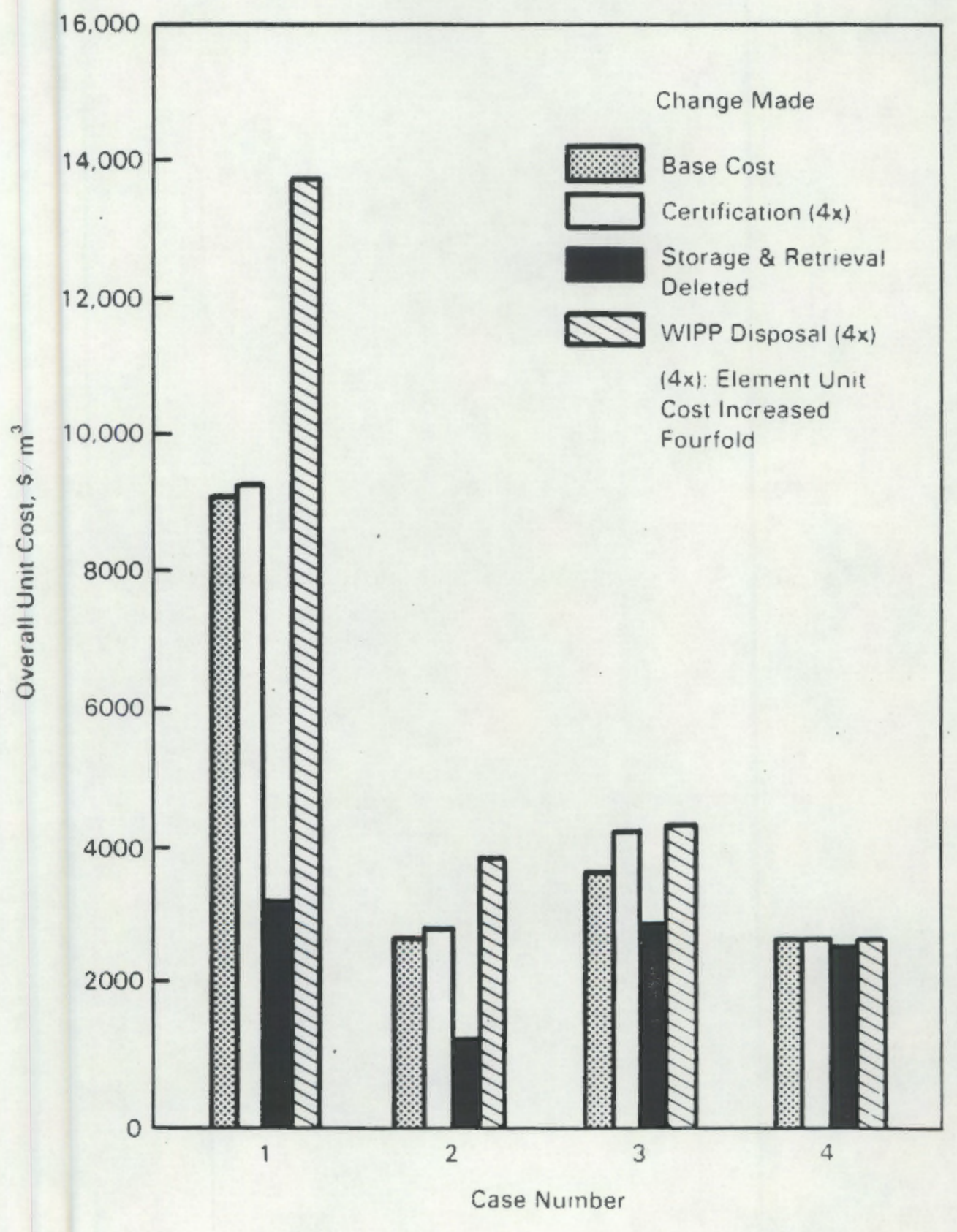

FIGURE 1. Sensitivity of Overal! Unit Cost to a Change in an Element Unit Cost for Processing TRU-Contaminated Glove Boxes (Truck Transportation) 


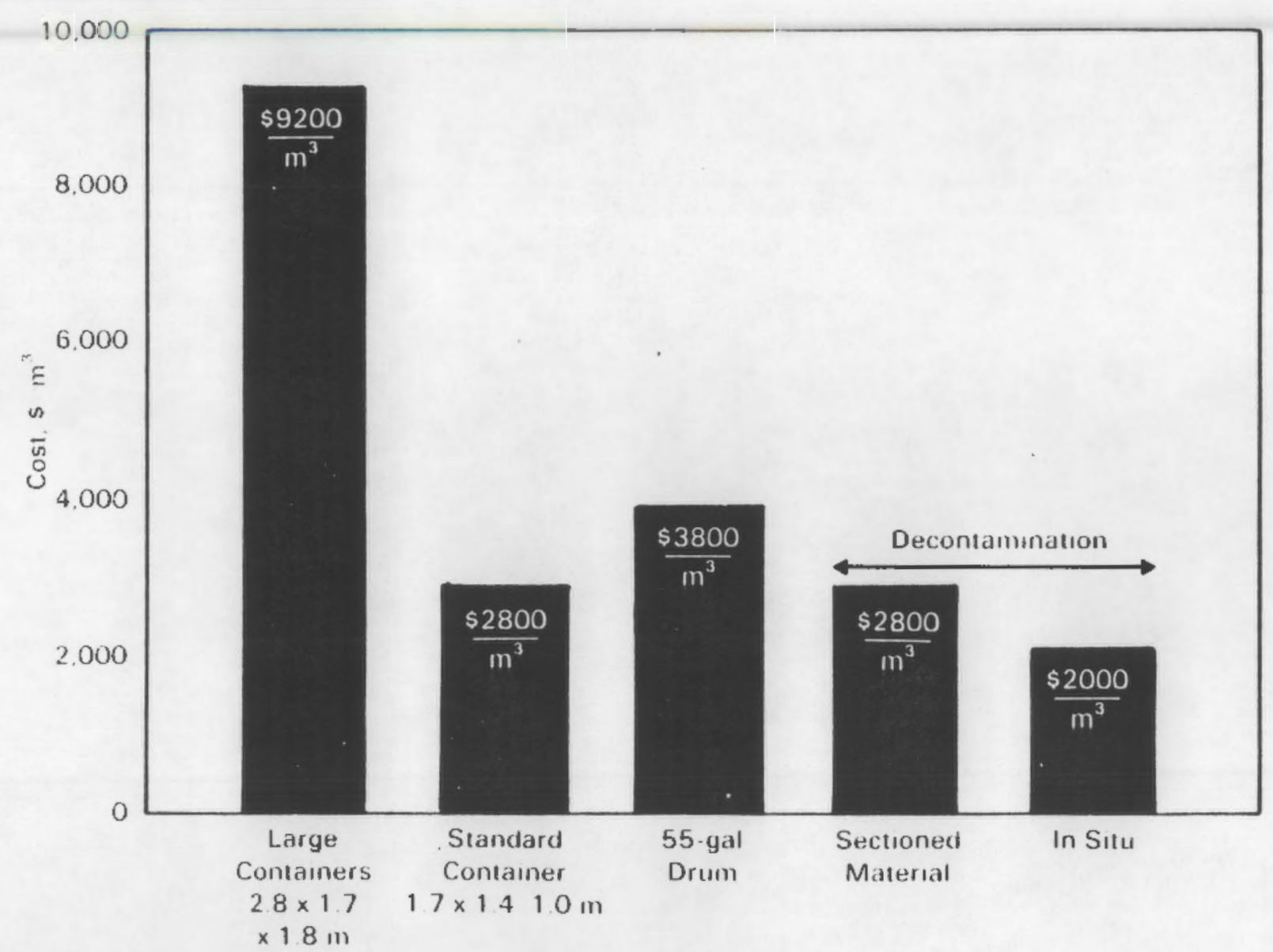

FIGURE 2. Total Unit Cost for TRU Waste Handling and Disposal Options, $\$ / \mathrm{m}^{3}$ of Original Glove Box Volume (Truck Transportation) 


\section{REFERENCES}

Allen, R. P. and R. F. Hazeiton. 1984. Conversion of Transuranic Waste to Low Level Waste by Decontamination - a Technical and Economic Evaluation. PNL-5315, Pacific Northwest Laboratory, Richland, Washington.

Allen, R. P. 1982. In Nuclear Waste Management Semiannual Progress Report April Through September 1982. PNL-4250-2, Pacific Northwest Laboratory, Richland, Washington, pp. 1.11-1.14.

Brown, C. M. 1982. Economic Evaluation of Volume Reduction for Defense Transuranic Waste. RFP-3245, Rockwell International, Golden, CoTorado.

Cadieux, J. R., et al. 1982. "A Pilot Scale, Alpha Disassembly and Decontamination Facility at Savannah River Laboratory". In Proceedings of the American Nuclear Society Topical Meeting on Treatment and Handling of Radioactive Waste (Richland, Washington), pp. 99-103, Battelie Press, Columbus-Richland.

McCoy, M. W., H. W. Arrowsmith and R. P. Allen. 1980. Vibratory Finishing as a Decontamination Process. PNL-3336, Pacific Northwest Laboratory, Richland, Washington.

McNair, G. W. et al. 1985, "Wastes: A Waste Management Logistics/ Economic Model". In Proceedings of the Symposium on Waste Management. Editors, R. G. Post and M. E. Weeks, Pp. 479-481, Volume 3, March 24-28, 1985, Tucson, Arizona.

Mitchell, 0. L., P. G. Aguilar and P. M. Williams. 1984. "Rocky Flats Advanced Size Reduction Facility." In Proceedings of the 1984 National Topical Meeting on Robotics and Remote Handling in Hostile Environments. American Nuclear Society, La Grange Park, ITTinois.

Oak Ridge National Laboratory. 1984. Spent Fuel and Radioactive Waste Inventories, Projections, and Characteristics. DOE/RW-0006, U.S. Department of Energy, Washington, DC. 
.

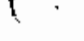

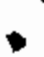

. 
APPENDIX A

COST ESTIMATION DETAILS

FOR TREATMENT/DISPOSAL OPTIONS 
APPENDIX A

COST ESTIMATION DETAILS

FOR TREATMENT/DISPOSAL OPTIONS

Inactive glove boxes contaminated with transuranics (TRU) could be handled and processed in several ways, including size reduction by disassembly and sectioning methods such as plasma arc torch for ultimate disposal. Disposal would be either at WIPP if the material remained TRU waste or at a low level waste (LLW) site if it were decontaminated. Descriptions of processes considered are given in the Size Reduction/ Decontamination Options Section along with unit cost comparisons. Cost estimation details are given here to show how the unit costs were obtained.

The cases examined to estimate the unit costs associated with the size reduction and decontamination of glove boxes are summarized below:

Case 1. No size reduction or decontamination. Glove boxes are disposed of intact at WIPP in an overpack container $2.8 \mathrm{~m} \mathrm{long}, 1.7 \mathrm{~m}$ wide, $1.8 \mathrm{~m}$ high.

Case 2. Size reduced to about one-half the initial volume. Glove box parts disposed of at WIPP in TRUPACT space efficient containers having dimensions of $1.7 \mathrm{~m}$ long, $1.4 \mathrm{~m}$ wide, $0.97 \mathrm{~m}$ high.

Case 3. Size reduced to about one-quarter the initial volume. Glove box parts disposed of at WIPP in 55-gal drums assembled into six-packs.

Case 4. About the same size reduction as case 3. Glove box parts decontaminated by vibratory finishing and disposed of in 55-gal drums as LLW at the Hanford site. Secondary TRUcontaminated wastes placed into 55-ga 1 drums and solidified. Drums grouped as six-packs and disposed of at WIPP. 
CASE 1 DETAILS

Waste Form for Disposal

It is assumed for all cases that the waste form is that of two typical glove boxes and three conveyor sections, representing a total waste volume of $8.92 \mathrm{~m}^{3}$, a total weight of $1,510 \mathrm{~kg}$, and having an average waste density of $170 \mathrm{~kg} / \mathrm{m}^{3}$ (Allen 1982). In this case, glove boxes are disposed of intact; in other cases size reduction is performed.

Overpack Container Cost

The overpack assumed for WIPP disposal is based on the Mound Laboratory (Dayton, Ohio) container design. This disposal container has a usable volume of $7.47 \mathrm{~m}^{3}$ and weighs $907 \mathrm{~kg}$.

Two glove boxes $\left(8.92 \mathrm{~m}^{3}\right)$ will not fit into the disposal container; consequently, only one glove box weighing $757 \mathrm{~kg}$ is placed into an overpack container. The resulting waste packing density is $100 \mathrm{~kg} / \mathrm{m}^{3}$.

Assuming an annual waste volume of $180 \mathrm{~m}^{3} / \mathrm{yr}$, based on newiy generated metal waste at the Hanford site as given by Brown (1982), and $4.47 \mathrm{~m}^{3}$ per glove box, the number of glove boxes disposed of per year would be 40.5 . Values other than $180 \mathrm{~m}^{3}$ could be used to derive the same unit costs $\left(\$ / \mathrm{m}^{3}\right)$; this number was used because it has been cited. The number of glove boxes disposed of annually are given in fractions because their disposal is not fixed by time.

The cost of an overpack disposal container is estimated to be about $\$ 3,300$. This is based on a manufacturer's price list and graphs for approved waste disposal containers of various volumes. For 40.5 containers the annual cost would be $\$ 134,000$. The unit cost for containers using $180 \mathrm{~m}^{3}$ of waste disposed annually would be $\$ 739 / \mathrm{m}^{3}$ of original waste volume.

Certification Costs

It is assumed that the glove box waste is homogeneous and is certifiable when it is placed into the overpack disposal container. Glove box use history checks are estimated to take 2 manhours at $\$ 50$ per manhour; three manhours are required to complete certification of each 
waste disposal container, in this case one overpack disposal container for each glove box. The total annual cost for certification would be $\$ 10,000$ or $\$ 56 / \mathrm{m}^{3}$ of original waste.

Interim Storage Costs

The volume of disposal containers placed into interim storage annualiy would be $360 \mathrm{~m}^{3}$. The current unit cost for interim storage at the Hanford site is $\$ 1,216 / \mathrm{m}^{3}$. Thus the annual cost would be $\$ 442,000$ and the unit cost would be $\$ 2,440 / \mathrm{m}^{3}$ of original waste.

Retrieval Costs

Waste retrieval costs are about $\$ 1,770 / \mathrm{m}^{3}$. This gives an annua? cost of $\$ 640,000$ or $\$ 3,540 / \mathrm{m}^{3}$ of original waste volume.

Transportation Costs

Following retrieval, the certified waste would be shipped either by railroad or by truck to WIPP using the Transuranic Package Transporter (TRUPACT) system. Two overpack disposal containers with glove boxes can be placed lengthwise into a TRUPACT-I bimodal container having a cavity of $5.7 \times 1.7 \times 2.0 \mathrm{~m}$ and a weight of $15,000 \mathrm{~kg}(33,000 \mathrm{lb})$. The weight of a waste disposal container and a glove box would be $910 \mathrm{~kg}$ (container) $+757 \mathrm{~kg}$ (waste), for a total of $1,670 \mathrm{~kg}$. Two would weigh 2,400 kg (7,340 1b) for each TRUPACT container. Two TRUPACT containers having 4 overpack disposal contajners can be shipped on a railcar. The number of railroad shipments required per year is 10.12 for 40.5 containers.

\section{Railroad Transportation Costs}

Railroad shipping costs for over 1,000 miles one-way (McNair, et al. 1985) are derived by the following equation:

$$
\begin{aligned}
\text { General-freight rail cost }(\$) & =(5.34+0.0042 \text { *DIS }) \text { *FWT } \\
& +(4.97+0.0039 * \text { DIS }) \text { *EWT }
\end{aligned}
$$

where DIS = one-way miTeage

FWT $=$ loaded weight of TRUPACT $-I, \mathrm{cwt}$ (a)

EWT = empty weight of TRUPACT-I, cwt

(a) cwt - abbreviation for hundred weight, a unit of weight used in commerce equat to $1001 \mathrm{~b}$. 
The approximate distance traveled per day for a distance of 1986 miles is $182 \mathrm{mi}$ (McNair, et a1. 1985). This plus two days turnaround at each end gives a round trip time of 26 days. Lease cost for TRUPACT containers is $\$ 800 /$ day. For two TRUPACT containers, the total lease cost for 26 days would be $\$ 14,000$ per round trip.

Considering freight and lease costs the total annual cost for 10.12 shipments is $\$ 339,000$ which gives a transportation unit cost of $\$ 1,871 / \mathrm{m}^{3}$ of original glove box volume.

Truck Transportation Costs

Truck shipping costs (Nair et al. 1985) for one-way mileage greater than 1,000 miles are derived by the following equation:

$$
\text { Shipping } \begin{aligned}
\cos t(\$) & =(0.0049 \star D I S-0.16) \star F W T \\
& +(0.0040 \star D I S-0.19) \star E W T
\end{aligned}
$$

Only one TRUPACT container can be shipped per truck. The shipping cost of each round trip of 8 days including turnaround time would be about $\$ 5,618$. The TRUPACT container lease cost would be $\$ 2,160$ per shipment to give a total transportation cost per shipment of $\$ 7,778$. The annual cost for 20.25 shipments would be $\$ 158,000$ which gives the unit cost of $\$ 870 / \mathrm{m}^{3}$ of original waste volume. Shipping by truck is Tess than half that of shipping by railroad.

\section{TRU Waste Disposal Costs at WIPP}

The WIPP operation costs have not been firmly established. However, a value used in preliminary estimates by a Rocky Flats Plant subcontractor is $\$ 773 / \mathrm{m}^{3}$. This value is used in this study.

The outside dimensions of the overpack disposal container give a disposal volume of $9.0 \mathrm{~m}^{3}$, or $360 \mathrm{~m}^{3} / \mathrm{yr}$ for 40.5 containers. The annual cost for disposal is $\$ 281,000$. This total gives a unit cost of $\$ 1,550 / \mathrm{m}^{3}$ of original waste volume. 


\section{Size Reduction Costs}

No size reduction is performed in this case. However there are some miscellaneous handling activities that are included in this category. A unit cost updated from that by Allen (1982) of $\$ 47 / \mathrm{m}^{3}$ of original waste volume is used.

Total Unit Costs

The annual costs calculated as described above are based on an annual waste generation volume of $180 \mathrm{~m}^{3}$. This was used solely for calculating the unit costs, $\$ / \mathrm{m}^{3}$ of original glove box volume. For this case the estimated individual unit costs total $\$ 10,200 / \mathrm{m}^{3}$ if waste is transported by railroad and $\$ 9,200 / \mathrm{m}^{3}$ if waste is shipped by truck.

\section{CASE 2 DETAILS}

\section{Waste Form For Disposal}

In this case glove boxes are disassembled and size reduced to about one half the original volume giving a packing density of about $350 \mathrm{~kg} / \mathrm{m}^{3}$.

\section{Disposal Container Costs}

The annual volume of waste disposed is reduced to $87 \mathrm{~m}^{3}$ from the base of $180 \mathrm{~m}^{3}$. The $1.7 \times 1.4 \times 0.97 \mathrm{~m}$ (DOT Type A) container has a usable volume of about $2.3 \mathrm{~m}^{3}$. The number of containers required per year is 37.6. By using the same cost source for containers as in Case 1 a container cost is estimated to be $\$ 820$. The annual container cost would be $\$ 30,800$ for a unit cost of $\$ 170 / \mathrm{m}^{3}$ of original glove box volume.

\section{Certification Costs}

The cost for glove box history checks would be the same as that for Case 1, $\$ 4,050 /$ year. The labor cost for 37.6 containers/year (3 manhours/ container, $\$ 50 /$ manhour) would be $\$ 5,640$ to give a total certification cost of $\$ 9,700$ and a unit cost of $\$ 53 / \mathrm{m}^{3}$. Interim Storage and Waste Retrieval Costs

The external volume of the waste disposal container is about $2.4 \mathrm{~m}^{3}$. The annual cost at $\$ 1,216 / \mathrm{m}^{3}$ for 37.6 containers is $\$ 111,400$ 
which gives a unit cost of $\$ 615 / \mathrm{m}^{3}$ of original glove box volume. Similarly, the retrieval costs at $\$ 1770 / \mathrm{m}^{3}$ of stored volume is $\$ 893 / \mathrm{m}^{3}$ of original giove box volume.

Transportation Costs

Eight disposal containers using volume as the basis could be placed into a TRUPACT container; however, the maximum cargo weight for a TRUPACT weighing $15,000 \mathrm{~kg}$ is $7,700 \mathrm{~kg}$. Eight disposal containers, weighing $215 \mathrm{~kg}$ each empty, having a usable volume of $2.3 \mathrm{~m}^{3}$ for waste having a density of $350 \mathrm{~kg} / \mathrm{m}^{3}$ would weigh $8,270 \mathrm{~kg}$. Thus only $7 \mathrm{con}-$ tainers weighing $7,230 \mathrm{~kg}$ loaded can be placed into a TRUPACT container. With the annual waste volume being $87.3 \mathrm{~m}^{3}$, the number of railroad shipments using two TRUPACT containers per shipment would be 2.69 . If trucks were used the number of single TRUPACT shipments would be 5.37 . Using the same equations as in Case 1 for shipping costs and adding TRUPACT lease costs, the annual costs are $\$ 96,400$ for rail and $\$ 45,700$ for truck. Unit costs are $\$ 531 / \mathrm{m}^{3}$ for rail transportation and $\$ 252 / \mathrm{m}^{3}$ of original glove box volume for truck transportation.

TRU Waste Disposal Costs

The external volume of the disposal container is about $2.4 \mathrm{~m}^{3}$. The annual cost for disposal of 37.6 containers at WIPP, using $\$ 773 / \mathrm{m}^{3}$ of disposal volume, is $\$ 70,700$. This gives a unit cost of $\$ 390 / \mathrm{m}^{3}$ of original glove box volume.

\section{Size Reduction}

Allen (1982) gives $\$ 349 / \mathrm{m}^{3}$ for size reduction. This value escalated to 1985 by using a 1.17 factor $(a)$ is $\$ 407 / \mathrm{m}^{3}$ of original glove box volume.

(a) The three-year escalation factor was estimated from hourly earnings indices published regularly in Chemical Engineering magazine and the Monthly Labor Review, a U.S. Department of Labor, Bureau of Labor Statistics publication. 
Total Unit Costs

For this case the estimated individual unit costs total $\$ 3,100 / \mathrm{m}^{3}$

if waste is transported by railroad and $\$ 2,800 / \mathrm{m}^{3}$ of origina? glove box volume if transported by truck.

\section{CASE 3 DETAILS}

Waste Form for Disposal

In this case glove boxes are reduced in size to about one-quarter of the original volume giving a packing density of $657 \mathrm{~kg} / \mathrm{m}^{3}$.

The size reduced waste would be placed in 55-gal drums. After retrieval from storage and before being shipped to WIPP, the drums would be joined into six-packs by bracing. This cost is inciuded in the cost of containers.

Disposal Container Costs

The annual waste volume is reduced to $47 \mathrm{~m}^{3} / \mathrm{yr}$ from the base of 180 $\mathrm{m}^{3}$. The waste is placed in 55-gal TRU drums numbering 225 per year. The cost for $225 /$ year is $\$ 15,800$. Added to this is the cost of bracing at $\$ 50$ per six-pack. This is an escalated value from that used by Brown (1982). The total annual cost is $\$ 17,600$ which gives a unit cost of $\$ 97 / \mathrm{m}^{3}$ of original glove box volume.

\section{Transportation Costs}

Because of volume 1 imitations only 6 six-packs of 55-gal drums can be placed into a TRUPACT container. Thus a shipment of six-packs by rail car would consist of 72 drums in two TRUPACT containers, and a shipment by truck, 36 drums in one TRUPACT. With bracing weighing $91 \mathrm{~kg}$, the total six-pack weight would be $1,090 \mathrm{~kg}$. A loaded TRUPACT container would weigh about $21,800 \mathrm{~kg}$. The number of 72 -drum rail shipments would be 3.12 annually; the number of 36-drum truck shipments would be 6.25 annually. The same equations used in case 1 were used to calculate shipping costs. Shipping costs and TRUPACT lease costs give transportation unit costs of $\$ 469 / \mathrm{m}^{3}$ of original glove box by rail and $\$ 290 / \mathrm{m}^{3}$ by truck. 
These unit costs could be decreased if other wastes than those considered here were added to a TRUPACT container to improve the volume shipping efficiency.

\section{TRU Waste Disposal Costs}

Although the 55-gal drums of waste are collected into six-packs, the WIPP disposal costs are expected to be based on the external volume of the drums rather than that of the whole six-pack. Consequently, the unit cost for disposal would be $\$ 244 / \mathrm{m}^{3}$ of original glove box volume. Tota 1 Unit Costs

The total unit cost if TRU waste is shipped by rail is $\$ 4,000 / \mathrm{m}^{3}$; by truck, $\$ 3,800 / \mathrm{m}^{3}$ of original glove box volume.

\section{CASE 4 DETAILS}

This case differs from the others in that sectioned glove box parts are decontaminated before disposal. The drummed material is handled as LLW instead of TRU waste and disposed of at the Hanford site rather than being shipped to WIPP for disposal. Waste data used were taken from Allen (1982).

\section{Waste Form}

Glove boxes are size reduced to essentially the same disposal volume as that of Case 3 . Decontamination allows the butk of the waste to be disposed of as LLW. Allen (1982) showed that $96 \%$ of the origina] waste volume is converted to LLW leaving $4 \%$ including secondary waste to be TRU waste.

\section{Disposal Container Costs}

Both the LLW and TRU waste are disposed of in 55-gaT drums. Using the same density as in Case $3\left(660 \mathrm{~kg} / \mathrm{m}^{3}\right)$ the number of drums required each year is 225. Nine of these drums would be used for TRU waste, the remainder for LLW. The TRU waste drum cost used was $\$ 70$ each; the LLW drum, $\$ 30$ each. The unit cost is: $\$ 40 / \mathrm{m}^{3}$ of originat waste volume. Bracing cost for nine drums is negligible. 


\section{Certification Costs}

The costs for glove box history checks would remain the same as before, $\$ 4,050$, as this information would still be needed. The labor cost for certifying $g$ drums would be $\$ 1,350$ annually giving an annual cost of $\$ 5,400$. The unit cost then is $\$ 30 / m^{3}$ of original glove box volume.

Interim Storage and Retrieval

The same unit costs as those used in Case 3 are used. This results in a unit cost of $\$ 13 / \mathrm{m}^{3}$ for interim storage of TRU waste drums and $\$ 18 / \mathrm{m}^{3}$ of original glove box volume for retrieval.

\section{Transportation Costs}

Drums placed into six-packs as in Case 3 would be transported to WIPP at the rate of 9 per year. This results in unit costs for transportation of $\$ 19 / \mathrm{m}^{3}$ for rajiroad and $\$ 12 / \mathrm{m}^{3}$ of original glove box volume by truck.

TRU Waste Disposal Costs

The annual cost for disposing of 9 drums is $\$ 1,772$, or $\$ 10 / \mathrm{m}^{3}$ of original glove box volume. This assumes that the cost of WIPP disposal would remain the same, $\$ 773 / \mathrm{m}^{3}$ of waste volume disposed.

\section{Size Reduction and Decontamination Costs}

Allen (1982) gives a unit cost of $\$ 2,210 / \mathrm{m}^{3}$ of original glove box volume for sectioning and decontamination. This cost is primarily for labor. It does not include capital recovery costs for facilities or maintenance costs. The 1985 unit cost using hourly earnings indexes is $\$ 2,600 / \mathrm{m}^{3}$.

\section{LLW Disposal Costs}

The current charge at the Hanford site for non-transuranic waste disposal is $\$ 136 / \mathrm{m}^{3}$. The annual cost for disposing 216 drums having a disposal volume of $0.21 \mathrm{~m}^{3}$ each is $\$ 6,200$. This gives a unit cost of $\$ 34 / m^{3}$ of original glove box volume. 
Total Unit Costs

The total unit costs (rounded) for this case are $\$ 2,800 / \mathrm{m}^{3}$ of original glove box volume if TRU waste is shipped by railroad or by truck. 


\section{DISTRIBUTION}

No. of

Copies

OFFSITE

30 COE Tech. Information Center

P. Hagan

Joint Integration Office

2201 San Pedro NE

Building 4, Second Floor

Albuquerque, IM 87110

2 DOE Office of Defense

Waste \& Byproducts Management GTN

Washington, DC 20545

Attn: D. B. LeClaire, DP-12

A. L. Taboas, DP-12

B. Helton

E. I. du Pont de Nemours \& Co.

Savannah River Plant

Building 706-1 $\mathrm{H}$

P.0. Box A

Aiken, SC 29808

R. Jaeger

Nuclear Waste Technology

Mound Facility

Monsanto Research Corp.

P.0. Box 32

Miamisburg, OH 45342

T. Keenan

Los Alamos National Laboratory

P.0. Box 1663

Los Alamos, NM 87545

R. H. Karisson

Rockwell Internationa?

Rocky Flats Plant

P.0. Box 464

Mai1 Stop LA-001

Golden, CO 80402-0464

J. $\log a n$

EG\&G Idaho, Inc.

P.0. Box 1625

Idaho Falls, ID 83401
No. of

Copies

F. Schultz

Oak Ridge Nationa1 Laboratory

Box X

Oak Ridge, TN 37830

D. Ziegler

Rockwell International

Rocky Flats Plant

P.0. Box 464

Golden, CO 20402-0464

L. J. Smith

Rockwell International

Rocky Flats Plant

P.0. Box 464

Mail Stop LA-001

Golden, CO 80402-0464

J. Warren

Los Alamos National Laboratory

P.0. Box 1663

Los Alamos, NM 87545

Ian Edwards

Rockwell International

Rocky Flats Plant

P.0. Box 464

Mai1.Stop LA-100

Golden, CO 80402-0464

Drew Detamore

Rockwel1 International

Rocky Flats Plant

P.0. Box 464

Mail Stop LA-100

Golden, CO 80402-0464

D. M. Lund

DOE/ALO

Waste Mgmt. \& Transportation

P.0. Box 5400

B. Pechin

Oak Ridge National Laboratory

Box $X$

Oak Ridge, TN 37830 
No. of

Copies

M. H. McFadden

TRU Waste Program Manager

Waste Mgmt. \& Transportation

Development Division

U.S. Department of Energy

Albuquerque Operations Office

P.0. Box 5400

Albuquerque, $N$ N 87115

T. H. Smith

EG\&G Idaho, Inc.

P. 0. Box 1625

Idaho Falls, ID 23401

\section{ONSITE}

3 DOE Richland Operations Office

E. A. Bracken

N. T. Karagianes

J. D. White

Rockwell Hanford Operations

G. Beitel

64 Pacific Northwest Laboratory

R. P. Allen (30)

H. C. Burkholder

J. R. Divine

L. K. Fetrow

C. A. Geffen

R. F. Hazelton (20)

C. H. Kindle

R. L. Lundgren

M. W. McCoy

Publishing Coordination (2)

Technical Information (5) 